\section{Deficit Irrigation on Growth of Baby Spinach (Spinacia oleracea L.) Cultivars Grown in Varied-textured Soils}

\author{
Boitumelo Patience Lekgoathi \\ Department of Crop Sciences, Tshwane University of Technology, Private \\ Bag X680, Pretoria, 0001, South Africa
}

Puffy Soundy

Department of Crop Sciences, Tshwane University of Technology, Private Bag X680, Pretoria, 0001, South Africa

\section{Pholosho Mmateko Kgopa \\ Department of Plant Production, Soil Science and Agricultural Engineering, University of Limpopo, Private Bag X 1106, Sovenga, 0727, South Africa}

Additional index words. baby spinach, dash, deficit irrigation, growth, 'Hellios', soil texture, Spinacia oleracea

\begin{abstract}
Water scarcity coupled with an increasing demand for water in agriculture has forced farmers to amend their irrigation practices and water management strategies. The proposed study was aimed at evaluating physiological and growth traits [photosynthesis rate, stomatal conductance $\left(g_{S}\right)$, chlorophyll content, leaf area, and fresh weight] under three irrigation levels $(50 \%, 75 \%$, and $100 \%$ of field capacity) in five varied textured soils (clay, clay loam, loam, sandy loam, and sandy). Response was evaluated on two baby spinach (Spinacia oleracea L.) cultivars (Dash and Hellios). Regarding physiological parameters, there were no interaction effects of deficit irrigation (DI) $\times$ soil texture. Significant increase on growth parameters (chlorophyll content, leaf weight, and leaf area) were observed under the interaction of $75 \%$ DI $\times$ sandy loam and loam soils on both 'Dash' and 'Hellios' during Season 1. 'Hellios' was able to adapt to deficit level of $75 \%$ during both growing seasons (summer and winter) under sandy loam soils. The study indicated that $25 \%$ water can be saved under sandy loam and loam soils when cultivating baby spinach during winter conditions.
\end{abstract}

Rapid population increases, economic growth, and urbanization have led to excessive usage of fresh water globally, resulting in decreased water availability per capita in most developing countries (Asghar et al., 2019). In South Africa, irrigation constitutes $60 \%$ of water withdrawals, which is relatively higher than other sectors, such as manufacturing industries and municipalities (FAO, 2016). Deficit irrigation scheduling in agriculture conserves scarce water resources, increases grower profitability, and reduces environmental pollution (Nakawuka, 2013). Deficit irrigation is defined as "an optimization strategy under which plants are exposed to a certain level of

Received for publication 4 Nov. 2021. Accepted for publication $25 \mathrm{Jan} .2022$.

Published online 8 March 2022.

Sincerest gratitude to Tshwane University of Technology, University of Limpopo, National Research Foundation and Deutscher Akademischer Austauschdienst for successful collaboration and financial support.

B.P.L. is the corresponding author. E-mail:

boitypatience@gmail.com.

This is an open access article distributed under the CC BY-NC-ND license (https://creativecommons. org/licenses/by-nc-nd/4.0/).

water stress significantly affecting growth and yield of plants" (Agbemafle et al., 2015). Several studies indicated the efficacy of deficit irrigation in saving irrigation water and improving plant water use efficiency (Nagaz et al., 2012; Shammout et al., 2018; Yang et al., 2015).

Baby spinach (Spinacia oleracea L.) is a leafy-green commodity plant considered healthy and convenient for increasing consumption of fresh produce (Kase et al., 2012). Spinach refers to heterogeneous species in diverse countries. Colloquial species of spinach in South Africa are Swiss chard (Beta vulgaris L.) and baby spinach (S. oleracia). Baby spinach can be consumed both cooked and as fresh leaves in salads (Mudau et al., 2015). Baby spinach is an extremely nutritious vegetable because it provides core nutrients, such as vitamins $\mathrm{A}, \mathrm{C}$, and $\mathrm{K}$; minerals; calcium; potassium; and dietary fiber (Ali et al., 2013; Zhang et al., 2014; Zikalala et al., 2017). Production of baby spinach is not prevalent in South Africa (Mudau et al., 2017). Rambuda et al. (2018) indicated that the demand for baby spinach exceeds the supply in retail stores; hence, South Africa has become the net importer of baby spinach from countries such as China and the United
States. However, Statistics South Africa (2002) estimated production of baby spinach at $\pm 18,000$ tons, with Limpopo Province being the largest producer compared with the other eight provinces (www.statssa.gov.za). Water and soil are preharvest factors that influence plant growth, quality, and yield of vegetable crops, including baby spinach. However, water is becoming both a scarce and crucial resource in most SubSaharan African countries. Therefore, it is imperative to explore innovative alternative measures of water for irrigation purposes (Kgopa et al., 2018).

Soils used for vegetable production differ in chemical and physical properties. These differences influence fertilizer and moisture content, which in turn affects the growth of vegetables (Makus and Lester, 2002). Soil texture also plays a vital role in interactive relationships between climate, soil, and vegetation, which are dependent on soil moisture dynamics and corresponding vegetation water stress (Fernandez-Illescas et al., 2001). Baby spinach thrives in fertile, well-drained soils rich in organic matter (Drost, 2010). Anwar et al. (2017) indicated that baby spinach biomass increased significantly without using organic manure treatments, especially in sandy loam. Sandy loam soils were preferred, with a $\mathrm{pH}$ of $6.0-7.5$, to avoid manganese deficiency, which causes leaves to turn yellow (Taunya et al., 2012). Applying water only when it is required by the plant and applying it to the active root zone depth minimizes water loss and use. However, different soil textures have different rates at which water drains from saturation, which could negatively affect the growth, quality, and yield of baby spinach (Kaur et al., 2020). Therefore, it is imperative to establish conducive deficit irrigation levels for planting baby spinach, which will have a positive and interactive relation with soil texture.

\section{Materials and Methods}

Study area. The experiment was conducted at University of Limpopo, South Africa (lat. $23^{\circ} 53^{\prime} 10^{\prime \prime} \mathrm{S}, 29^{\circ} 44^{\prime} 15^{\prime \prime} \mathrm{E}$ ). The University of Limpopo is located in a semiarid area in Limpopo Province (near Polokwane city), with winter temperatures ranging from 16 to $18^{\circ} \mathrm{C}$ (minimum) and from 20 to $30^{\circ} \mathrm{C}$ (maximum) and summer temperatures ranging from 18 to $22^{\circ} \mathrm{C}$ (minimum) and from 28 to $38^{\circ} \mathrm{C}$ (maximum). Humidity ranges from $30 \%$ to $40 \%$ (minimum) and from $85 \%$ to $95 \%$ (maximum) (South African Weather Service, 2018). The experiments were conducted in a white shade net house with $40 \%$ sunshine ultraviolet blocking rate. The experiments were run over two seasons: winter (June-July 2018) and summer (Nov.-Dec. 2018).

Study design. The experiment was laid out as a 3 (three irrigation levels) $\times 5$ (five different soil textures) factorial study arranged in a randomized complete block design, with five replications. The growth response was observed on two baby spinach cultivars (Dash and Hellios). A total of 150 pots were 
used, with 75 pots administered for 'Dash' and the other 75 for 'Hellios'.

Soil sampling and preparation. Soils of five different textures were collected and analyzed for basic fertility parameters (Bourget and Kemp, 1957; Diaz-Zorita et al., 2002) (Table 1). Soil texture treatments included clay, clay loam, loam, sandy loam, and sand. Three kilograms of different soil types were loaded in each of the $20-\mathrm{cm}$ pots and irrigated to field capacity before planting. First planting for Season 1 was done on 4 June 2018, and the first planting for Season 2 was on 5 Nov. 2018. Five seeds were sown in each pot, and seedlings were thinned after $14 \mathrm{~d}$ of sowing (after the plant had developed two leaves); three plants were left in the pots.

Irrigation scheduling. Irrigation was monitored throughout the growing season until the plants were harvested at full maturity (at 4 weeks). Irrigation scheduling was performed using soil water balance, which predicts water requirement and generates irrigation calendars (Fessehazion et al., 2014; Lashari et al., 2010). Irrigation treatments commenced $14 \mathrm{~d}$ after germination and seedling emergence. Irrigation treatments were $100 \%$ irrigation (control) and deficit levels of $75 \%$ and $50 \%$ from 25 $\mathrm{mm}$ water required for baby spinach. Water content measurements were carried out using the gravimetric method.

Fertilization. Baby spinach requires $45 \mathrm{~kg} \cdot \mathrm{ha}^{-1}$ of nitrogen fertilizer and 22 $45 \mathrm{~kg} \cdot \mathrm{ha}^{-1}$ of $\mathrm{P}_{2} \mathrm{O}_{5}$ at planting; however, potassium can be applied if soils have less than 120 ppm acetate-exchangeable potassium (Koike et al., 2011). Fertilization was derived from the spinach fertilizer recommendations and post soil test in Table 1. Fertilizer was applied in the form of fertigation. Before planting, Multifeed 19:8:16 (43) was applied, and at vegetative stage $107 \mathrm{~mL}$ LAN (28) per pot sample was applied.

Data collection. Plant physiological parameters $\left(g_{\mathrm{S}}\right.$, photosynthesis rate, and leaf area) were measured at harvest on the abaxial side of the leaf using a portable photosynthesis system (ADC Bio Scientific, Hoddesdon, United Kingdom) for each season. All plant physiological parameters were measured simultaneously under steady-state condition in full sun between 10:00 AM and 2:00 PM (Mabapa et al., 2018). Leaf chlorophyll content was measured using a nondestructive method with a SPAD 502 chlorophyll meter (Konica Minolta Co. Ltd., Tokyo, Japan) (Mudau et al., 2017) at planting for three consecutive weeks. Weight was determined using a weighing scale at harvest.

Data analysis. The data were analyzed using the Statistix 10 statistical package. Data were subjected to analysis of variance. Tukey's honestly significant difference test was used to calculate mean differences at $P=0.05$ to check the level of significance.

\section{Results}

Photosynthetic rate. There was no significant $(P>0.05)$ variation on interactions of deficit irrigation and soil texture on
Table 1. Preliminary results of soil fertility analysis.

\begin{tabular}{lccccc}
\hline Texture & $\mathrm{pH}\left(\mathrm{H}_{2} \mathrm{O}\right)$ & $\mathrm{pH}(\mathrm{KCl})$ & $\mathrm{EC}\left(\mathrm{dS} \cdot \mathrm{m}^{-1}\right)$ & $\mathrm{N}\left(\mathrm{mg} \cdot \mathrm{kg}^{-1}\right)$ & $\mathrm{P}\left(\mathrm{mg} \cdot \mathrm{kg}^{-1}\right)$ \\
\hline Clay & $7.045 \mathrm{~b}^{\mathrm{z}}$ & $5.085 \mathrm{~b}$ & $0.111 \mathrm{e}$ & $7.564 \mathrm{bc}$ & $8.509 \mathrm{~b}$ \\
Clay loam & $6.535 \mathrm{c}$ & $4.475 \mathrm{~b}$ & $0.189 \mathrm{a}$ & $7.356 \mathrm{~cd}$ & $8.291 \mathrm{~b}$ \\
Loam & $6.185 \mathrm{~d}$ & $4.95 \mathrm{~b}$ & $0.174 \mathrm{c}$ & $8.112 \mathrm{~b}$ & $8.216 \mathrm{~b}$ \\
Sandy loam & $6.57 \mathrm{c}$ & $5.335 \mathrm{~b}$ & $0.184 \mathrm{~b}$ & $8.766 \mathrm{a}$ & $10.779 \mathrm{a}$ \\
Sand & $8.905 \mathrm{a}$ & $6.97 \mathrm{a}$ & $0.136 \mathrm{~d}$ & $6.91 \mathrm{~d}$ & $7.091 \mathrm{c}$ \\
LSD $^{\mathrm{y}}$ & 0.201 & 0.086 & 0.001 & 0.583 & 0.976 \\
Significance & $* *$ & $* *$ & $* *$ & $* *$ & $* *$ \\
\hline
\end{tabular}

${ }^{\bar{z}}$ Column means followed by the same letter are not significantly different according to Tukey's least significant difference test.

${ }^{y_{\text {LSD }}}$ (mean separation for comparison).

*Significant at $P \leq 0.05$. **Highly significant at $P \leq 0.01$. photosynthetic rate during the two seasons for both cultivars. Significant differences occurred solely on the effect of deficit irrigation on photosynthetic rate and the effect of soil texture on photosynthetic rate. An increase in photosynthetic rate was observed for $75 \%$ DI during Season 1 (Table 2) on 'Dash', whereas the least photosynthetic rate was observed in clay soils during both seasons. A decrease in water ( $75 \%$ DI) resulted in an increase in photosynthetic rate for 'Hellios' during both seasons.

Stomatal conductance. Similar to photosynthetic rate, there were no significant $(P>$ $0.05)$ interactions of deficit irrigation with soil texture on $g_{\mathrm{S}}$ in the two seasons for both cultivars. There were also no significant variations of deficit irrigation on $g_{\mathrm{S}}$ for 'Hellios' during both seasons (Table 3). Significance was observed on effect of soil texture on $g_{\mathrm{S}}$, whereby the lowest $g_{\mathrm{S}}$ rate occurred mostly in clay and sandy soils.

Chlorophyll. Chlorophyll content was measured for 3 weeks before harvesting. There were significant interactions of deficit irrigation and soil texture during the 3 weeks. However, chlorophyll content increased at each week of measurement during both seasons. Higher chlorophyll content was observed under the interaction of $100 \%$ and $75 \%$ DI $\times$ loam soil during Season 1 (Fig. 1A) on 'Dash'. However, during Season 2, an increase in chlorophyll content occurred at $100 \%$ and $75 \%$ DI $\times$ sandy loam soil (Fig. 1B). Also, an increase in chlorophyll content on 'Hellios' occurred on the interaction of $75 \%$ DI $\times$ sandy loam soils during both seasons (Fig. 1C and D). For both soils in the two seasons, $50 \%$ and $75 \%$ DI $\times$ clay soils and clay loam soils showed similar trends of greater chlorophyll content than the $100 \%$ control treatment (Fig. 1A-D).
Yield parameters. Significant variations were also observed for leaf area and leaf mass during both seasons of the two cultivars. Similarly, to chlorophyll content, $100 \%$ irrigation with clay soil resulted in a decrease in leaf area and leaf mass (Fig. 2A-D). However, a decrease in water level $(50 \%$ and $75 \%)$ increased leaf area and leaf mass in clay and clay loam soils during both seasons compared with the $100 \%$ control treatment. An increase in leaf number was observed under $75 \%$ DI $\times$ sandy loam soils in the shade house (Fig. 1E and F). A decrease in leaf area was observed under all irrigation levels - sandy soils and clay soils, whereby all treatments were less than $6 \mathrm{~cm}^{2}$ during both seasons in shade house and field.

\section{Discussion}

Water deficit irrigation had a significant effect on stomatal (pores on leaf surface through which plants exchange $\mathrm{CO}_{2}$ and water vapor) density, indicating adaptation to drought conditions (Du et al., 2015). There were no significant interactions between deficit irrigation and soil texture for $g_{\mathrm{S}}$ and photosynthesis rate of both baby spinach cultivars during two seasons. However, there were significant effects on single factors (i.e., effect of deficit irrigation on photosynthesis rate or effect of soil texture on $g_{\mathrm{S}}$ ). Different genotypes have been found to vary in photosynthetic rate, $g_{\mathrm{S}}$, and transpiration rate, thus showing varying water deficit responses (Chai et al., 2016). We observed that $g_{S}$ increased with decreasing water levels. This was in contrast with the findings of Lawlor's (2002), which indicated that decreasing water levels significantly decreased $g_{\mathrm{S}}$ and lowered
Table 2. Effect of deficit irrigation on photosynthetic rate and stomatal conductance $\left(g_{\mathrm{S}}\right)$ of 'Dash'.

\begin{tabular}{|c|c|c|c|c|}
\hline \multirow[b]{2}{*}{$\begin{array}{l}\text { Treatment } \\
\text { (irrigation level) }\end{array}$} & \multicolumn{2}{|c|}{ Season 1} & \multicolumn{2}{|c|}{ Season 2} \\
\hline & $\begin{array}{l}\text { Photosynthetic rate } \\
\qquad\left(\mu \mathrm{mol} \cdot \mathrm{m}^{2} \cdot \mathrm{s}^{-1}\right)\end{array}$ & $\frac{g_{\mathrm{S}}}{\left(\mu \mathrm{mol} \cdot \mathrm{m}^{2} \cdot \mathrm{s}^{-1}\right)}$ & $\begin{array}{l}\text { Photosynthetic rate } \\
\left(\mu \mathrm{mol} \cdot \mathrm{m}^{2} \cdot \mathrm{s}^{-1}\right)\end{array}$ & $\frac{g_{\mathrm{S}}}{\left(\mu \mathrm{mol} \cdot \mathrm{m}^{2} \cdot \mathrm{s}^{-1}\right)}$ \\
\hline $100 \%$ & $5.76 \mathrm{ab}^{\mathrm{z}}$ & $181.6 \mathrm{ab}$ & $4.75 \mathrm{a}$ & $173 \mathrm{ab}$ \\
\hline $75 \%$ & $6.91 \mathrm{a}$ & $214.5 \mathrm{a}$ & $4.26 \mathrm{a}$ & $192 \mathrm{a}$ \\
\hline $50 \%$ & $4.36 \mathrm{~b}$ & $158.1 \mathrm{~b}$ & $3.14 \mathrm{~b}$ & $168 \mathrm{~b}$ \\
\hline $\operatorname{LSD}^{\mathrm{y}}$ & 1.17 & 28.8 & 40.1 & 23.4 \\
\hline Significance & ** & $*$ & $*$ & $*$ \\
\hline
\end{tabular}

${ }^{\mathrm{z} C o l u m n}$ means followed by the same letter are not significantly different according to Tukey's least significant difference test.

$\mathrm{y}_{\text {LSD (mean separation for comparison). }}$

* Significant $P \leq 0.05$. **Highly significant $P \leq 0.01$. 
Table 3. Effect of deficit irrigation on photosynthetic rate and stomatal conductance $\left(g_{\mathrm{S}}\right)$ of 'Hellios'.

\begin{tabular}{lccccc}
\hline & \multicolumn{2}{c}{ Season 1} & & \multicolumn{2}{c}{ Season 2} \\
\cline { 2 - 3 } \cline { 5 - 6 } $\begin{array}{l}\text { Treatment } \\
\text { (irrigation level) }\end{array}$ & $\begin{array}{c}\text { Photosynthetic rate } \\
\left(\mu \mathrm{mol} \cdot \mathrm{m}^{2} \cdot \mathrm{s}^{-1}\right)\end{array}$ & $\begin{array}{c}g_{\mathrm{S}} \\
\left(\mu \mathrm{mol} \cdot \mathrm{m}^{2} \cdot \mathrm{s}^{-1}\right)\end{array}$ & & $\begin{array}{c}\text { Photosynthetic rate } \\
\left(\mu \mathrm{mol} \cdot \mathrm{m}^{2} \cdot \mathrm{s}^{-1}\right)\end{array}$ & $\begin{array}{c}g_{\mathrm{S}} \\
\left(\mu \mathrm{mol} \cdot \mathrm{m}^{2} \cdot \mathrm{s}^{-1}\right)\end{array}$ \\
\hline $100 \%$ & $5.92 \mathrm{~b}^{\mathrm{z}}$ & $0.09 \mathrm{a}$ & & $3.03 \mathrm{ab}$ & $0.2 \mathrm{a}$ \\
$75 \%$ & $9.58 \mathrm{a}$ & $0.12 \mathrm{a}$ & & $3.5 \mathrm{a}$ & $0.17 \mathrm{a}$ \\
$50 \%$ & $9.44 \mathrm{a}$ & $0.08 \mathrm{a}$ & & $2.88 \mathrm{~b}$ & $0.16 \mathrm{a}$ \\
$\mathrm{LSD}^{\mathrm{y}}$ & 1.28 & 0.038 & & 0.25 & 0.028 \\
Significance & $*$ & $\mathrm{NS}$ & & $*$ & $\mathrm{NS}$ \\
\hline
\end{tabular}

${ }^{\mathrm{z}}$ Column means followed by the same letter are not significantly different according to Tukey's LSD test.

${ }^{\mathrm{L}} \mathrm{LSD}$ (mean separation for comparison).

*Significant at $P \leq 0.05$. **Highly significant at $P \leq 0.01$. ns, not significant at $P \geq 0.05$.

$\mathrm{CO}_{2}$ uptake. Photosynthetic rate and $g_{\mathrm{S}}$ were high in sandy loam soils on both cultivars during two seasons. Similarly, Wan and Sosebee (1990) reported that photosynthesis rates were greater $(P<0.01)$ in plants growing on sandy loam soils than in those growing in clay loam soils. This might be due to sandy loam soils having large pore size and thus greater aeration. Fanourakis et al. (2015) reported that larger pore space in soil increases stomatal size. A lower photosynthetic rate occurred in clay soils with $100 \%$ irrigation during both seasons in the field and in a greenhouse. This was attributed by poorly structured nature of clay soils with low oxygen and poor aeration. Furthermore, oxygen availability was lower due to most air spaces being filled with water (Poorter et al., 2016).

There was a significant decrease of nitrogen availability on both cultivars, primarily due to baby spinach requiring large amounts of nitrogen (Nemadodzi et al., 2017; Zikalala et al., 2017). Gutiérrez-Rodríguez et al. (2013) also reported incremental gain in leaf weight due to an increase in nitrogen supply in baby spinach. Therefore, the plant feeds on nitrogen to sustain optimal plant growth and other important leaf parameters. Interaction effects of deficit irrigation and soil texture were found for chlorophyll content of the two cultivars during both seasons. Low chlorophyll contents were mostly in clay and sandy soils in all irrigation levels. Also, clay soils are known to be rich in nutrients, but, due to their poor drainage, the nutrients and water are often withheld from plants. Low chlorophyll content also occurred in $50 \%$ DI in all soil textures compared with control $(100 \%)$ and $75 \%$ DI. This might be because mild drought increases chlorophyll content, whereas severe drought could lead to chlorophyll degradation (Valenca et al., 2017). Both cultivars showed similar increases under the interaction of $75 \% \times$ loam and sandy loam soils, including the $100 \%$ control treatment with sandy and loamy soils during Season 1 . A similar trend was observed for leaf weight, leaf area, and leaf number, which are yield constituents of baby spinach. However, these findings are in contrast with findings ReyesGonzález et al. (2018), who indicated the highest leaf weight (fresh weight) on full irrigation. The lowest leaf area and weight were mostly in clay and clay loam soils with 'Dash'. Similarly, Senyigit and Kapla (2013) reported low plant weight, height, and diameter of lettuce (Lactuca sativa L.) plants under water deficit regimes in clay loam soils. Furthermore, Zhang et al. (2014) observed higher spinach yield due to increases in leaf weight under deficit irrigation in sandy loam soils. These might be due to the ability of sandy loam soils to retain soil moisture and nutrients, eventually leading to increases in leaf area and thereby increasing yield for consumer market. Also, well-drained, moderately fertile sandy loam soils are preferred for most vegetative growth of various plants (Abdulazeez, 2017).

In conclusion, from the results in the current study, it is evident that deficit irrigation can be adopted for baby spinach cultivation. However, deficit can be further enhanced by taking into consideration soil texture. Also, season has an influence together with cultivar type. The $75 \%$ DI $\times$ sandy loam and loam soils interactions showed increases in growth traits of both cultivars compared with the $100 \%$ water control treatment. Therefore, the study suggests that $25 \%$ water can be saved
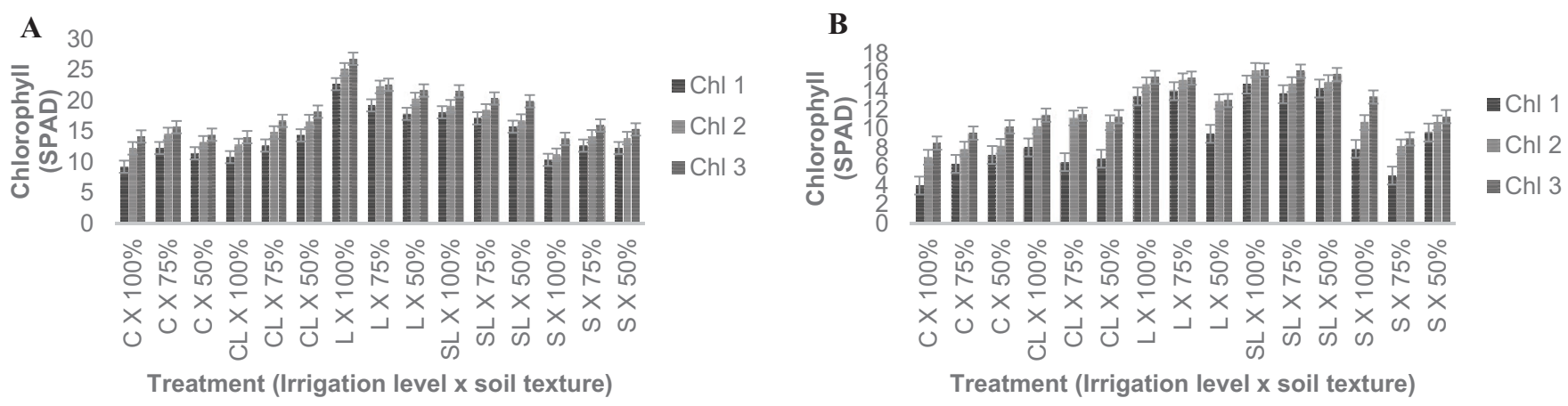

C

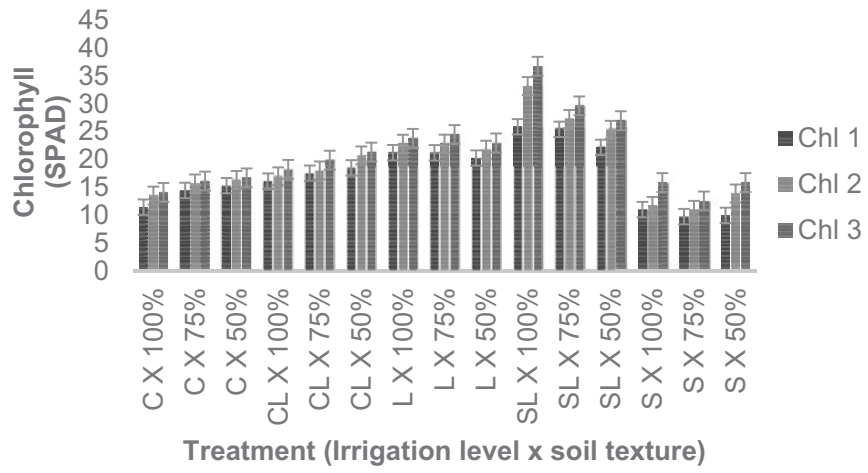

D

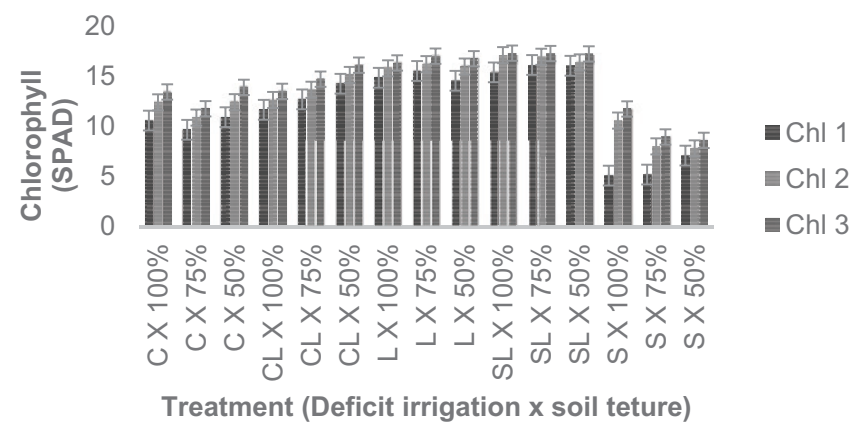

Fig. 1. Interaction of deficit irrigation and soil texture on chlorophyll content of (A) 'Dash' during Season 1, (B) 'Dash' during Season 2 , (C) 'Hellios' during Season 1, and (D) 'Hellios' during Season 2 measured for three consecutive weeks. 

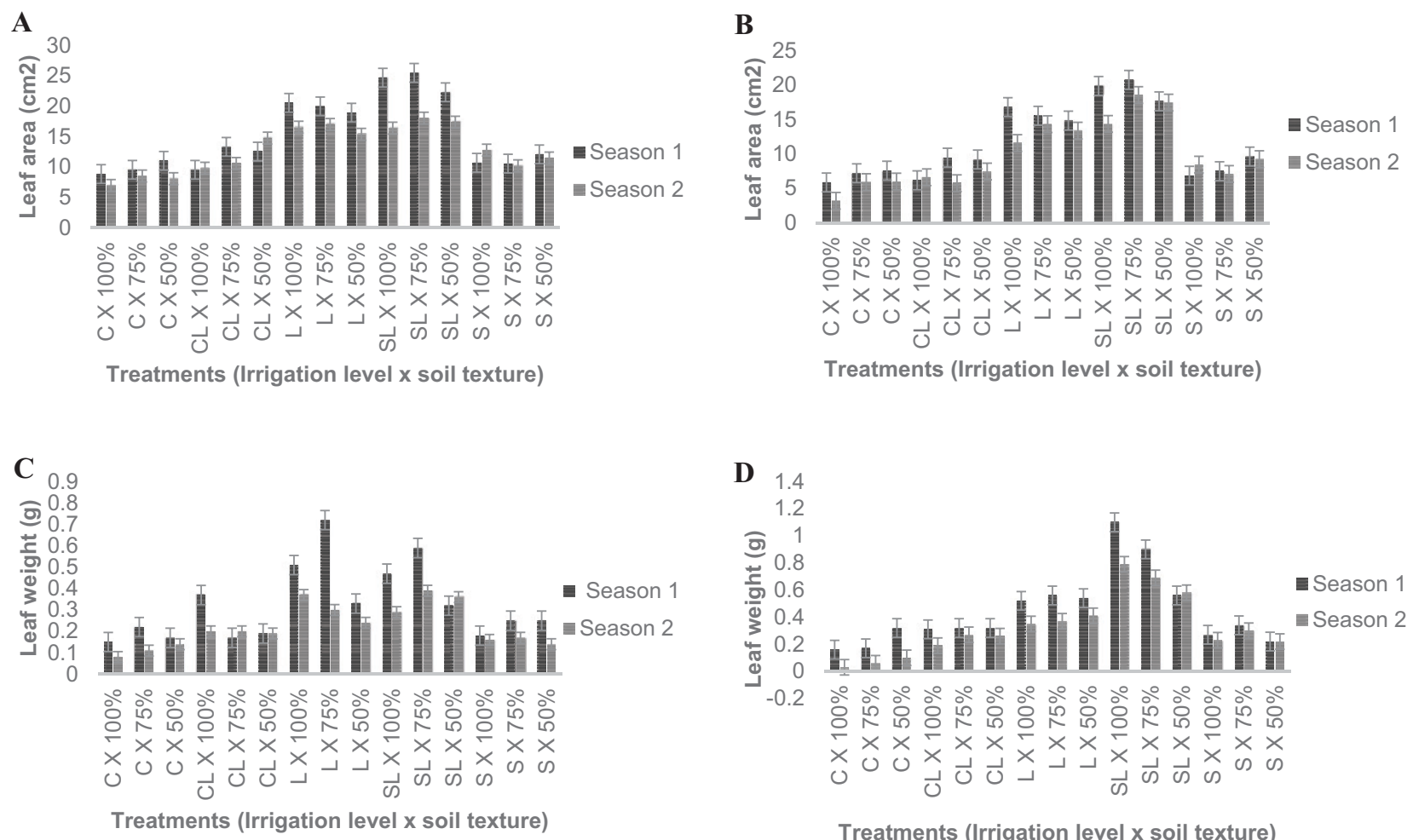

Treatments (Irrigation level x soil texture)
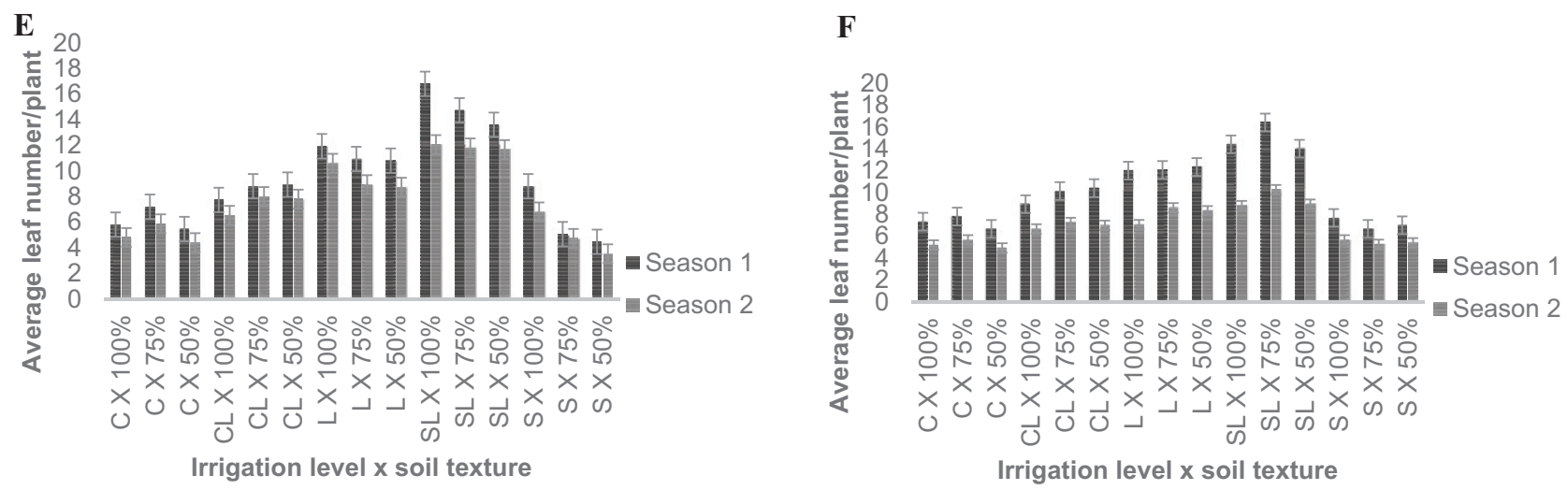

Fig. 2. Interaction of deficit irrigation and soil texture on yield parameters. (A) Leaf area of 'Dash'. (B) Leaf area of 'Hellios'. (C) Leaf weight of 'Dash'. (D) Leaf weight of 'Hellios'. (E) Average leaf number of 'Dash'. (F) Average leaf number of 'Hellios'.

when cultivating baby spinach in sandy or loam soil for optimum growth and yield.

\section{Literature Cited}

Abdulazeez, A. 2017. Effects of soil texture on vegetative and root growth of Senna obtusifolia seedlings indigenous to Bichi Sudan savannah of northern Nigeria in green house conditions. IOSR J. Agr. Vet. Sci. 10:70-74, https://doi. org/10.9790/2380-1004027074.

Agbemafle, R., J.D. Owusu-Sekyere, and A. BartPlange. 2015. Effect of deficit irrigation and storage on nutritional composition of tomato (Lycopersicon esculentum Mill. cv. Pectomech). Croat. J. Food Tech. Biotechnol. Nutr. 10(2):59-65.

Ali, A.H., M.M. Hafez, A.R. Mahmoud, and M.R. Shafeek. 2013. Effects of bio and chemical fertilizers on growth, yield and chemical properties of spinach plant (Spinacia oleracea L.). Middle East J. Agr. Res. 2(1):16-20.

Anwar, Z., M. Irshad, Q. Mahmood, F. Hafeez, and M. Billal. 2017. Nutrient uptake and growth of spinach as affected by cow manure co-composted with poplar leaf litter. Int. J. Recycle Org. Waste Agr. 6:79-88, https://link.springer.com/ article/10.1007/s40093-017-0154-x.

Asghar, A., J. Iqbal, A. Amin, and L. Ribbe. 2019. Integrated hydrological modelling for assessment of water demand and supply under socio-economic and IPCC climate change scenarios using WEAP in Central Indus Basin. J. Water supply: Res. Technol. Aqua 68(2):136-148, https://doi.org/ 10.2166/aqua.2019.106.

Bourget, S.J. and J.G. Kemp. 1957. Wet sieving apparatus for stability analysis of soil aggregates. Can. J. Soil Sci. 37(1):60-61, https://doi. org/10.4141/cjss57-009.
Chai, Q., Y. Gan, C. Zhao, H. Xu, R.M. Waskom, Y. Niu, and K.H.M. Siddique. 2016. Regulated deficit irrigation for crop production under drought stress. A review. Agron. Sustain. Dev. 36:3, https://doi.org/10.1007/s13593-015-0338-6.

Diaz-Zorita, M., E. Perfect, and J.H. Grove. 2002. Disruptive methods for assessing soil structure. Soil Tillage Res. 64:3-22, https://doi.org/ 10.1016/S0167-1987(01)00254-9.

Drost, D. 2010. Spinach in the garden. Utah State Univ., Coop. Ext. <https://extension.usu.edu/ yardandgarden/research/spinach-in-the-garden $>$.

Du, T., S. Kang, J. Zhang, and W.J. Davies. 2015. Deficit irrigation and sustainable water-resource strategies in agriculture for China's food security. J. Expt. Bot. 66(8):2253-2269, https://doi. org/10.1093/jxb/erv034.

Fanourakis, D., H. Habtamu, R. Milla, R. Pieruschka, K.H. Kjaer, M. Bolger, A. Vasilevski, A.N. Nesi, F. Foriano, and C.O. Ottosen. 2015. 
Pore size regulates operating stomatal conductance, while stomatal densities drive partitioning of conductance between leaf sides. Ann. Bot. 115(4):555-565, https://doi.org/10.1093/ $\mathrm{aob} / \mathrm{mcu} 247$.

FAO. 2016. Food and Agriculture Organization of the United Nations Land \& Water AQUASTAT. https://doi.org/10.1016/j.advwatres.2017.08.012.

Fernandez-Illescas, C.P., A. Porporato, F. Laio, and I. Rodriguez-Iturbe. 2001. The ecohydrological role of soil texture in a water-limited ecosystem. Water Resour. Res. 37(12):2863-2872, https://doi.org/10.1029/2000WR000121.

Fessehazion, M.K., J.G. Annandale, C.S. Everson, R.J. Stirzaker, M. van der Laan, W.F. Truter, and A.B. Abraha. 2014. Performance of simple irrigation scheduling calendars based on average data for annual ryegrass. African J. Range For. Sci. 31(3): 221-228, https://doi.org/10.2989/ 10220119.2014.906504.

Gutiérrez-Rodríguez, E., H.J. Lieth, J.A. Jernstedt, J.M. Labavitch, T.V. Suslow, and M.I. Cantwell. 2013. Texture, composition, and anatomy of spinach leaves in relation to nitrogen fertilization. J. Sci. Food Agr. 93(2):227-237, https://doi.org/10.1002/jsfa.5780.

Lashari, B.K., K.Q. Laghari, and A.M. Phul. 2010. Development of an irrigation scheduling model. Mehran Univ. Res. J. Eng. \& Technol. 29(4):681-688.

Lawlor, D.W. 2002. Limitation to photosynthesis in water-stressed leaves, stomata vs metabolism and role of ATP. Ann. Bot. 88(7):871-885, https://doi.org/10.1093\%2Faob\%2Fmcf110.

Kaur, G., G. Singh, P.P. Motavalli, K.A. Nelson, J.M. Orlowski, and B.R. Golden. 2020. Impacts and management strategies for crop production in waterlogged or flooded soils: A review. Agron. J. 112(3):1475-1501, https://doi.org/ 10.1002/agj2.20093.

Kase, J.A., S. Borenstein, R. Blodgett, and P.C. Feng. 2012. Microbial quality of bagged baby spinach and romaine lettuce effects of top versus bottom sampling. J. Food Prod. 75(1):132-136, https://doi.org/10.1093\%2Faob\%2Fmcf110.

Kgopa, P.M., P.W. Mashela, and A. Manyevere. 2018. Suitability of treated wastewater with respect to $\mathrm{pH}$, electrical conductivity, selected cations, and sodium adsorption ratio for irrigation in a semi-arid region. Water S.A. 44:551-556, https://doi.org/10.4314/wsa.v44i4.04.

Koike, S.T., M. Cahn, M. Cantwell, S. Fennimore, M. Lestrange, E. Natwick, R.F. Smith, and E. Takele. 2011. Spinach production in California. Univ. California, Veg Res. \& Info. Ctr., VRICuCDAVIS.Edu. https://doc.anrcatalog.ucanr. edu/pdf/7212.pdf.
Mabapa, P., I.K. Mariga, and K. Ayisi. 2018. Seasonal effect on Moringa oleifera gaseous exchange and water use efficiency under diverse planting densities. J. Appl. Bot. Food Qual. 91:219-225, https:// doi.org/10.5073/JABFQ.2018.091.029.

Makus, D.J. and G. Lester. 2002. Effect of soil type, light intensity, and cultivar on leaf nutrients in mustard greens. Subtropical Plant Sci. 54:23-28, https://pubag.nal.usda.gov/ catalog/57410.

Mudau, A., F.N. Mudau, and P. Soundy. 2017. Response of baby spinach (Spinacia oleracea L.) to photoselective nettings on growth and postharvest quality. HortScience 52(5):719-724, https://doi.org/10.21273/HORTSCI11875-17.

Mudau, A.R., H.T. Araya, and F.N. Mudau. 2018. The quality of baby spinach as affected by development stage as well as postharvest stage conditions. Acta Agr. Scandinavica, Sec. BSoil. Plant Sci., https://doi.org/10.1080/09064 710.2018.1492009.

Mudau, A.R., N.M. Nkomo, P. Soundy, H.T. Araya, W. Ngezimana, and F.N. Mudau. 2015. Influence of postharvest storage temperature and duration on quality of baby spinach. HortTechnology 25(5):665-670, https://doi.org/10. 21273/HORTTECH.25.5.665.

Nagaz, K., M.M. Mamoudi, and N.B. Mechila. 2012. Effect of deficit drip-irrigation scheduling regimes with saline water on pepper yield, water productivity and soil salinity under arid conditions of Tunisia. J. Appl. Hort. 14(1):18-24, https://doi.horticultureresearch.net/jah/2012_14_ 1_18_24.PDF.

Nakawuka, P. 2013. Effect of deficit irrigation on yield, quality and grower returns of native spearmint and hops in Washington State. Washington State University, Pullman, PhD Diss. https:// www.proquest.com/openview/8a9c6516162d04 abb889ff68a50d7970/1?pq-origsite $=$ gscholar \& $\mathrm{cbl}=18750$.

Nemadodzi, L.E., H. Araya, M. Nkomo, W. Ngezimana, and F.N. Mudau. 2017. Nitrogen, phosphorus and potassium effects on the physiology and biomass yield of baby spinach (Spinacia oleracea L.). J. Plant. Nutr. 40: 2033-2044. https://doi.org/10.1080/01904167.2017. 1346121.

Poorter, H., F. Fiorani, R. Pieruschka, T. Wojciechowski, W. Van Der Putten, M. Kleyer, U. Schurr, and J. Postma. 2016. Pampered pestered outside, differences and similarities between plants growing in controlled conditions and in field. New Phytol. 212:838-855, https://nph.onlinelibrary.wiley.com/doi/10.1111/ nph.14243.

Rambuda, A., H.T. Araya, and F.N. Mudau. 2018. The quality of baby spinach as affected by development stage as well as postharvest stage conditions. Acta Agr. Scandinavica, Sec. BSoil. Plant Sci., https://doi.org/10.1080/ 09064710.2018.1492009.

Reyes-González, A., J. Kjaersgaard, T. Trooien, C. Hay, and L. Ahiablame. 2018. Estimation of crop evapotranspiration using satellite remote sensingbased vegetation index. Adv. Meteorol. 2018(1): 1-12, https://doi.org/0.1155/2018/4525021.

Senyigit, U. and D. Kapla. 2013. Impact of different irrigation water levels on yield and some quality parameters of lettuce (Lactuca sativa L. var. longigolia $\mathrm{cv}$.) under unheated greenhouse. Polska. Acad. Nauk 2(4):97-107.

Shammout, M.W., T. Qtaishat, H. Rawabdeh, and M. Shatanawi. 2018. Improving water use efficiency under deficit irrigation in the Jordan Valley. Sustainability 10(11):4317, https://doi. org/10.3390/su10114317.

South African Weather Service. 2018. South African Weather Service. 6 May 2018. <http:// webportal.weathersa.co.za $>$.

Statistics South Africa. 2002. Report on large and small scale agriculture. 1 Feb. 2020. <www. Statssa.Gov.Za>.

Taunya, E., D. Drost, and B. Black. 2012. High tunnel winter spinach production. Utah.StateUniv.extension.usa.edu. 20 Aug. 2019. < https://digitalcommons. usu.edu/cgi/viewcontent.cgi? article $=1505 \&$ context $=$ psc_facpub $>$.

Valenca, D.C., D.F. De Carvalho, F. Reinert, R.A Azevedo, C.F. De Pinho, and L.O. Medici. 2017. Automatically controlled deficit irrigation of lettuce in organic potponics. Sci. Agr. 51(1):52-59, https://doi.org/10.1590/1678-992X2016-0331.

Wan, C. and R.E. Sosebee. 1990. Relationship of photosynthetic rate and edaphic factors to root carbohydrate trends in honey mesquite. J. Range Manage. 43(2):171-176.

Yang, C., Y. Luo, L. Sun, and N. Wu. 2015. Effect of deficit irrigation on growth, water use characteristics and yield of cotton in Arid Northwest China. Pedosphere 25(6):910-924, https:// doi.org/10.1016/S1002-0160(15)30071-0.

Zhang, J., Z. Bei, Y. Zhang, and L. Cao. 2014. Growth characteristics, water, and nitrogen use efficiencies of spinach in different water and nitrogen levels. Sains Malays. 43(11):1665-1671.

Zikalala, B.O., M. Nkomo, H. Araya, W. Ngezimana, and F.N. Mudau. 2017. Nutritional quality of baby spinach (Spinacia oleracea L.) as affected by nitrogen, phosphorus, and potassium fertilization. South African J. Plant Soil 34(2):79-86, https://doi.org/10.1080/02571862. 2016.1225231 . 